\title{
Analysis of the impact of determinant factors on foreign direct investment in Cambodia: The ARDL bounds testing approach
}

\author{
Chantha Hor *
}

Faculty of Business Administration, Vongchavalitkul University, Nakhon Ratchasima, Thailand

\author{
Keywords: \\ FDI \\ ARDL model \\ VECM model \\ Granger causality test \\ Cambodia
}

Received: 21 May 2016

Accepted: 18 July 2016

Published: 12 August 2016

\begin{abstract}
This study employs Auto Regressive Distributed Lag (ARDL) bounds testing approach and vector error correction model within Granger causality test to examine the time series data over the period of twenty-two years (1993-2014) in order to investigate the long and short-run relationships among Foreign Direct Investment (FDI) and its determinant factors, as well as the direction causality among variables. The study finds that GDP and FER have statistically and significantly positive relationships with FDI for both long- and short-run. This implies that an increasing GDP and foreign exchange reserve lead to an increase in the FDI inflows into Cambodia. But, TON has significant and negative long and short-run relationships with FDI, which is an unexpected result. Higher unskilled labors supplied in Cambodia discourage FDI inflows to the country. The political instability and deadlock in Cambodia have a negative short-run impact on FDI inflows. Moreover, a higher degree of trade openness and labor force in Cambodia cause increase in the GDP in Cambodia. The sign of ECM (t-1) coefficient is negative and significant as expected for all models, which indicates a relative speed of achieving the long-run equilibrium. This study suggests that the government should protect the internal political conflict as well as increased degree of trade openness and skilled labors in order to attract more FDI inflows into Cambodia.
\end{abstract}

(C) 2016 The Author(s). Published by TAF Publishing.

\section{INTRODUCTION}

Foreign Direct Investment (FDI) is one of the main pulses for growth and economic development, especially in the developing country like Cambodia. It is widely well-known that the FDI could produce economic benefits to the host countries by enhancing human capital, physical capital, foreign exchange, employment opportunities, productive capacity, money supply for domestic investment, the host

\footnotetext{
* Corresponding author: Chantha Hor
}

E-mail: chanthahor@hotmail.com country's skill labor through transferring technology and management skills (Belloumi, 2014; Mottaleb \& Kalirajan, 2010; Decastro, Fernandes \& Campos, 2013). Economically speaking, the FDI inflows foster country's economic growth via business and economic transition process between the host and home country. The FDI has played a significant role in the Cambodian economy for almost three decades since Cambodia received peace and political stability in 1993 through the first general election. Cambodia has transformed herself to an open economy and improved year-by-year on the level of economic freedom in order to attract FDI Phnom Penh Securities 
(Plc, 2011). Statistically, total FDI inflows in Cambodia increased from $\$ 68$ million in 1994 to $\$ 293$ million in 1996but fell to $\$ 131$ million in 2004. It showed statistically re-positive growth to $\$ 377$ million in 2005 , to $\$ 1.87$ billion in 2013, and yet slightly dropped to $\$ 1.73$ billion in 2014 . The main sources of foreign direct investment in Cambodia are China, South Korea, Malaysia, Japan, Hong Kong, Vietnam, Taiwan and the United States (Council for the Development of Cambodia). The most important sectors for FDI are services (banks, telecommunications, and tourism), apparel and textile industry, and the mining and agricultural sectors. The Cambodian government, to attract the FDI, has improved number of laws and regulations to encourage foreign investors to Cambodia. Cambodia offers a great incentive to investors such as the lowest corporate tax rate in the region, no tax on import duty, no discrimination between local and foreign investors, a hundred percent owning of a banking license and telecom sector as well as facilitates of no foreign exchange control. Also, the government has reformed a number of investment policies which help facilitate foreign investors more easily to access Cambodia market. However, the FDI does so much mean to Cambodia's economy, but there is little empirical research done to examine economic and non-economic variables' association with FDI in Cambodia. The aim of this paper was to investigate the long and short-run relationships among variables using advanced time series econometric analysis approach.

\section{LITERATURE REVIEW}

There are many past studies to investigate the determinant factors influencing the relationship with FDI in the host country, respectively. This paper simply categorizes the previous studies into the variables used, time series data, and panel data. First, numerous variables are used to identify the determinant factors' effect on FDI. Those variables are market size, domestic investment, external debts, trade openness, infrastructure, government consumption, indirect taxes, inflation, return on investment, portfolio diversification, resource location, foreign exchange reserves, internationalization, government regulation, borrowing costs, geographic distance, regional integration, political stability, foreign exchange rate, interest rate, gross fixed capital formation, public expenditure, total export, total import, government fiscal discipline, current account balance, political right, natural resource availability, corruption and bureaucratic red tape, labor cost, and corruption. These variables can be found in the papers of Demirhan \& Masca (2008), Onyeiwu (2003), Anfofum, Gambo \& Suleiman (2013), Azam \& Lukman (2010), Onuorah \& Nnenna, (2013), Uwubanmwen \& Ajao (2012), Teli (2014), Egbo \& Onwumere (2011), Tsen (2005), Cuyvers, Plasmans, Soeng \& Van den Bulcke (2008), Obidike \& Uma (2013), Asien \& Oriavwote (2013), Leopold \& Maniam (2006), Kunle, Olowe \& Oluwafolakemi (2014), Keorite, Bukhari \& Chantarat (2015), Khan \& Mitra (2014) and Mottaleb \& Kalirajan (2010). Second time series data, Anfofum et al., (2013) used the ordinary least square equation, cointegration, and Granger casualty techniques to investigate the relationship between FDI and economic growth in Nigeria. The finding indicates that FDI spurs export, gross fixed capital formation, and economic growth. The study shortly concludes that FDI is a positive measure of economic growth. Onuorah \& Nnenna (2013) studied the long-run relationship between macroeconomic variables and FDI in Nigeria. They used Vector Auto Regression (VAR) and impulse function techniques. The result shows there is a negatively strong relationship between FDI and GDP in the country suggesting an inverse relationship. Exchange rate, inflation rate, money supply, and interest rate directly impacted. Uwubanmwen \& Ajao (2012) examined the determinants and impact of FDI in Nigeria from 1970 to 2009 by employing the vector error correction model, and Granger causality methodology. The outcome shows that exchange rate, interest rate, inflation rate and openness of the economy determine the inflow of FDI into Nigeria during these periods. The government size and GDP have the positive, but insignificant influence on FDI. The findings also add that FDI and GDP have a longrun equilibrium relationship between FDI and GDP, but FDI has an insignificant effect on the growth as well as the development of Nigeria economy. Onuorah \& Nnenna (2013) used simple regression analysis to investigate the relationship between FDI and GDP in Cambodia. The result shows there is a positive relationship between FDI and GDP in the long run in Cambodia. Tsen (2005) used Johansen co-integration method and Fully-Modified Least Squares (FMLS) estimator to estimate the long-run relationship between FDI and its location-related determinants in the manufacturing industry of Malaysia. The result reveals an increase in education, infrastructure, market size or current account balance that leads to an increase in FDI, whereas an increase in inflation or 
exchange rate leads to a decrease. Bekhet \& Al-Smadi (2015) used the bound testing approach to measuring the long-run and short-run relationship between FDI inflows and their determinants in Jordan. The result shows there are long and short-run relationships between FDI and its determinants (GDP, economic openness, Consumer Price Index (CPI) and stock market index. The study also suggests that the Jordanian policymakers have to be aware of the importance of inward FDI in the Jordanian economy. Decastro et al., (2013) studied the determinants of FDI in Brazil and Mexico by using vector error correction model. The results record that in Brazil, the main multinationals' strategy is the market seeking linked to the size of the domestic market, and in Mexico, the dominant strategy seems to be efficiency seeking, related to the importance of trade liberalization and the historical flows attract FDI. Kiran (2011) studied the causal links between FDI and trade in Turkey using the vicariate VAR model. The result indicates that there is no evidence of causality between FDI and trade in Turkey. Almsfir, Latif \& Bekhet (2011) investigated and estimated the factors influencing FDI in Malaysia by employing ARDL model. The study indicates that there is a co-integration relation between FDI and its determinants in Malaysia. Third, panel data, Cuyvers, Soeng, Plasmans \& Van Den Bulcke (2011) analyzed the determinant factors that might influence inward FDI in Cambodia by using unbalanced panel datasets during 1995-2005. The result reveals that the FDI, home country's GDP, bilateral trade with the host country and the exchange rate have a positive impact on inward FDI flows into Cambodia. Geographic distance negatively affects the level of FDI inflows in Cambodia. Ho (2004) studied the determinants of foreign direct investment at the sect oral level in the Chinese economy. The results reveal that the large market size encourages inward foreign investments in both China and the Guangdong province, whereas the labor cost and state ownership level seem to have a negative effect on FDI inflows at a sect oral level in both China and the Guangdong province. Kersan-Skabic \& Tijanic (2014) studied the regional determinants of FDI in Croatia to identify the factors that influence FDI in Croatia. The results show that education, infrastructure, the manufacturing industry, dummy variables for areas of special state concern and the capital city region have the positive significant effect on FDI. Yet, unemployment and the dummy variable (border regions with the EU) significantly affect FDI. Rodriguez \& Pallas (2008) examined the determinants of FDI in Spain, at the sect oral level, by differentiating the manufacturing sectors, and at the regional level. The results suggest that the difference between labor productivity and the cost of labor has been an important determinant of FDI in Spain during the period 1993-2002. Hunady \& Orviska (2014) examined the key determinants of FDI in EU countries. The results suggest that there is the insignificant effect on corporate taxes on FDI, but there is a significant effect of labor costs, openness of the economy, firing costs, GDP per capita and public debt in the country. It also indicates some evidence of a negative impact of the financial and economic crisis on FDI inflows in the EU.

\section{METHODOLOGY}

The aim of this paper is to investigate the long and shortrun relationships between FDI inflows in Cambodia and its determination during the period of twenty-two years (1993-2014). This current study has used the ARDL bounds testing approach to co-integration developed by Pesaran, Shin \& Smith (2001) in order to fulfill the aim of the study. We employed this approach because of its several advantages. First, the approach works well with a small-sized sample data. Second, an order of integration of a series does not matter for applying the ARDL model if variables are not found stationary at the level I (2). Third, if there is some of the model re grassers that are endogenous, the approach still provides unbiased long-run estimates and valid t-statistics (Pesaran et al., 2001; Alhassan \& Fiador, 2014; Amusa, Amusa \& Mabugu, 2009). Fourth, within the general-to-specific framework, unrestricted version of the approach chooses the appropriate lag order to capture the data generating procedure. The proper modification of the order of ARDL model is effective to correct residual serial correlation and the endogeneity problem (Pesaran, Shin \& Smith, 1999).

Only selected explanatory variables are used in this study due to the limited data provided in the case of Cambodia. Therefore, in order to examine the long and short-run relationships among FDI inflows and its determinant factors, the following inward FDI-induced functional relationship is formulated:

$$
\mathrm{FDI}_{\mathrm{t}}=\mathrm{f}\left(\mathrm{GDP}_{\mathrm{t}}, \mathrm{TON}_{\mathrm{t}}, \mathrm{LAF}_{\mathrm{t}}, \mathrm{FER}_{\mathrm{t}}, \mathrm{D} 01\right)
$$

Or 
$\operatorname{lnFDI} I_{t}=\alpha_{0}+\alpha_{1} \operatorname{lnGDP}_{\mathrm{t}}+\alpha_{2} \operatorname{lnTON}_{\mathrm{t}}+\alpha_{3} \operatorname{lnLAF}_{\mathrm{t}}$

$$
+\alpha_{4} \operatorname{lnFER}_{\mathrm{t}}+\alpha_{5} \mathrm{D} 01+\varepsilon_{\mathrm{jt}}
$$

Where

$\mathrm{InFDI}_{\mathrm{t}}=$ logarithm of foreign direct investment inflows to

Cambodia during year $t$, Where $t$ is the period of 1993-2014.

$\operatorname{lnGDP}_{\mathrm{t}}=$ logarithm of gross domestic product at time $\mathrm{t}$.

$\operatorname{lnTON}_{\mathrm{t}}=$ logarithm of trade openness at time $t$.

$\operatorname{lnLAF}_{\mathrm{t}}=$ logarithm of the labor force at time $\mathrm{t}$.

$\operatorname{lnFER}_{t}=$ logarithm of foreign exchange reserve at time $t$.

D01 = political instability in Cambodia in 1998, 2003, 2008 and 2013-2014 for which D01 =1 in the period of 1998, 2003, 2008, 2013-2014, and Dummy $=0=$ otherwise.

$\alpha_{1}$ to $\alpha_{5}=$ the parameter of independent variables

$\alpha_{0} \quad=$ the intercept

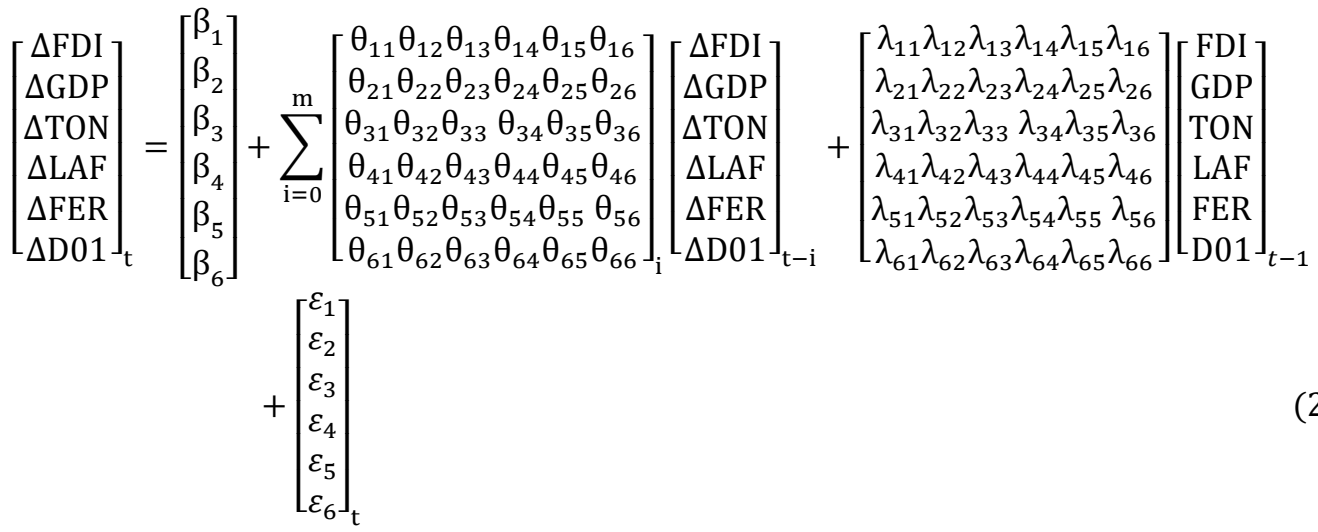

Where $\Delta$ the different operator; $\beta_{-} j(j=1, \ldots, 6)$ denotes intercept; $m$ is the maximum lag length; i is number of lags; $\theta_{-} \mathrm{jk}(\mathrm{j}, \mathrm{k}=1, \ldots 6)$ denotes the short-run coefficient of the variables; $\lambda_{-} \mathrm{j} \mathrm{k}(\mathrm{j}, \mathrm{k}=1, \ldots 6)$ denotes the long-run coefficient of the variables; and $\varepsilon_{-} \mathrm{j} t(\mathrm{j}=1, \ldots 6)$ presents the serial independent random error with mean zero and a finite covariance matrix. Moreover, hypothesis for testing longrun existence among variables could be formulated:

$\mathbf{H}_{\mathbf{0}}: \quad \lambda_{\_} \mathrm{j} \mathrm{k}=0$, No co integration

$\mathbf{H}_{\mathbf{1}}: \quad \lambda_{-} \mathrm{j} \mathrm{k} \neq 0$, co integration

To decide whether the variables have co-integration or no co-integration or inconclusive, we have to compare the calculated F-statistics value with critical values reported in the paper of Pesaran et al. (1999). If the estimated Fstatistics value is greater than the upper-bound critical value, the null hypothesis of no co-integration would be rejected. This implies that the variables in the model share $\varepsilon_{\mathrm{jt}}=$ error term

To achieve the study's objective, there are several steps of the econometric methodologies to be performed. First, we need to check and ensure that all variables are not at I (2) stationary level in order to avoid spurious result (Pesran et al., 2001). And, if the variables are stationary at I (2), the approach is not valid due to the assumption, i.e. the variables must be stationary at I (1), I (0) or mix (Bekhet \& A l-Smadi, 2015). This checking will be done by Augmented Dickey-Fuller (ADF) (Dickey and Fuller, 1979, 1981). Second, if the results of all variables are marked off no. I (2), ARDL bounds testing approach to co-integration can begin to find the presence of long-run relationships between explaining and explanatory variables. So, ARDL approach to co-integration model can be formed:

long-run relationship among themselves. In contrast, if the F-statistics value falls below the lower bound critical value, then the null hypothesis of no co-integration cannot be rejected. Therefore, the variables included in the model do not share long-run relationships among themselves. Furthermore, if the F-statistics value falls within the lower and upper bound critical values, then the conclusion is inconclusive to either accepted or rejected long-run relationship. Lastly, after a confirmation of long-run cointegration between GDP, TON, LAF, FER, D01 and FDI, we use Error Correction Model to obtain the short-run dynamic coefficients and estimate ECM (t-1) associated with the short-run estimates. The ECM $(t-1)$ shows the adjustment speed from the short-run to the long-run equilibrium among variables (Bekhet \& Al-Smadi, 2015) (Pesaran et al., 2001). Moreover, the Granger causality test is also employed to determine the causality relationship between variables. If there is co-integration among the 


$$
\begin{aligned}
{\left[\begin{array}{c}
\Delta \mathrm{FDI} \\
\Delta \mathrm{GDP} \\
\Delta \mathrm{TON} \\
\Delta \mathrm{LAF} \\
\Delta \mathrm{FER} \\
\Delta \mathrm{D} 01
\end{array}\right]=\left[\begin{array}{l}
\omega_{1} \\
\omega_{2} \\
\omega_{3} \\
\omega_{4} \\
\omega_{5} \\
\omega_{6}
\end{array}\right]+\sum_{\mathrm{i}=0}^{\mathrm{m}}\left[\begin{array}{c}
\theta_{11} \theta_{12} \theta_{13} \theta_{14} \theta_{15} \theta_{16} \\
\theta_{21} \theta_{22} \theta_{23} \theta_{24} \theta_{25} \theta_{26} \\
\theta_{31} \theta_{32} \theta_{33} \theta_{34} \theta_{35} \theta_{36} \\
\theta_{41} \theta_{42} \theta_{43} \theta_{44} \theta_{45} \theta_{46} \\
\theta_{51} \theta_{52} \theta_{53} \theta_{54} \theta_{55} \theta_{56} \\
\theta_{61} \theta_{62} \theta_{63} \theta_{64} \theta_{65} \theta_{66}
\end{array}\right]_{\mathrm{i}}\left[\begin{array}{c}
\Delta \mathrm{FDI} \\
\Delta \mathrm{GDP} \\
\Delta \mathrm{TON} \\
\Delta \mathrm{LAF} \\
\Delta \mathrm{FER} \\
\Delta \mathrm{D} 01
\end{array}\right]_{\mathrm{t}-\mathrm{i}}+\left[\begin{array}{l}
\varphi_{1} \\
\varphi_{2} \\
\varphi_{3} \\
\varphi_{4} \\
\varphi_{5} \\
\varphi_{6}
\end{array}\right]\left[\begin{array}{l}
\mathrm{ECM}_{1} \\
\mathrm{ECM}_{2} \\
\mathrm{ECM}_{3} \\
\mathrm{ECM}_{4} \\
\varepsilon_{2} \\
\varepsilon_{3} \\
\varepsilon_{3} \\
\varepsilon_{4} \\
\varepsilon_{5} \\
\varepsilon_{6}
\end{array}\right]_{t} }
\end{aligned}
$$

variables, then the vector error correction can be developed (Bekhet \& Al-Smadi, 2015): Where $\omega_{-} \mathrm{i}(\mathrm{i}=1, \ldots, 6)$ denotes the intercept; $\theta_{-} \mathrm{jk}(\mathrm{j}, \mathrm{k}=1, \ldots 6)$ denotes the shortrun coefficients $; \varphi_{-} i(i=1, \ldots, 6)$ presents the coefficients of the lagged error correction term (ECM_(t-1)) that describes the adjustment speed back to equilibrium (Pesaran et al., 1999). The sign of coefficients of ECM_(t1)must be negative and statistically significant (Pesaran et al., 2001.). Besides, Granger (1969) and Bekhet \& Al-Smadi (2015) suggest that if there is a confirmation of the presence of long-run relationships among the variables, there must be either bidirectional, unidirectional or neutral causality relationships among variables. If the variables are significant at the first differences, it indicates that the variables have a direction of short-run causality. On the other hand, if the coefficients of lagged error correction term are significant, this proves there is a longrun causality among variables. Furthermore, several diagnostic tests are performed in order to ensure that all the models are reliable. Those diagnostic tests are the serial correlation (Godfrey, 1978), normal distribution (Jarque \& Bera, 1980) heteroscedasticity (White, 1980), and the cumulative sum of recursive residuals (CUSUM) to assess the stability of the model.

\section{Data}

The annual time series data for all variables during the period of1993 to 2014 are used in this study to examine the long-run and short-run relationships between (GDP, TON, LAF, FER, and D01) variables and FDI in Cambodia. All variables are obtained from two main sources such as World Development Index and the CEIC database.

\section{RESULTS AND DISCUSSION}

\section{Unit Root Test Results}

All the variables are free of non-stationary at the level I (2) according to the results of ADF (Augmented Dickey-Fuller) test pintable 1. FDI, GDP, and TON are integrated order at I (1), while LAF, FER, and dummy (D01) are integrated order at both I (0) and I (1).

TABLE 1. Results of unit root test using ADF (augmented dickey-fuller) test

\begin{tabular}{llllll}
\hline \hline Variables & Level & & 1st different & & Conclusion \\
& constant & $\begin{array}{l}\text { constant } \\
\text { \&trend }\end{array}$ & Constant & constant \& trend & \\
\hline lnfdi & -1.0798 & -1.9517 & $-3.7805^{* *}$ & $-3.6717^{* *}$ & $\mathrm{I}(1)$ \\
lngdp & -0.4646 & -2.4401 & $-2.7662^{*}$ & -2.6866 & $\mathrm{I}(1)$ \\
Lnton & -1.7449 & -3.3686 & $-5.2943^{* * *}$ & $-5.3010^{* * * *}$ & $\mathrm{I}(1)$ \\
lnlaf & $-2.8587^{*}$ & -0.2734 & -1.3969 & $-6.6705^{* * *}$ & $\mathrm{I}(0), \mathrm{I}(1)$ \\
lnfer & $-4.3011^{* * *}$ & -1.9900 & $-10.6455^{* * *}$ & $-9.5650^{* * *}$ & $\mathrm{I}(0), \mathrm{I}(1)$ \\
D01 & $-5.5086^{* * *}$ & $-5.6072^{* * *}$ & $-6.9533^{* * *}$ & $-6.6060^{* * *}$ & $\mathrm{I}(0), \mathrm{I}(1)$ \\
\hline \hline
\end{tabular}

Note: $\left({ }^{* * *}\right),\left({ }^{* *}\right),\left({ }^{*}\right)$ represents $1 \%, 5 \%$ and $10 \%$ level of significance. 
The Results of Presence of Long-Run Relationship

Table2 shows that there is the presence of long-run relationships among FDI and its determinants (GDP, TON, LAF, and FER). The only $\Delta$ lnLAF_t model has the long-run relationship existence among variables at significance level of $10 \%$ while the other models are at significance level of
1\%. This conclusion is determined by computed Fstatistics. The findings are in line with the works of Bekhet \& Al-Smadi (2015), Onuorah \& Nnenna (2013), Almsafir, Latif \& Bekhet (2011), Imoudu (2012), and Adam \& Tweneboah (2009).

TABLE 2. Co-integration test results

\begin{tabular}{|c|c|c|c|c|c|}
\hline \multirow[t]{2}{*}{ Model series } & \multirow[t]{2}{*}{ F-statistic } & \multirow{2}{*}{$\begin{array}{l}\text { Significance } \\
\text { level }\end{array}$} & \multicolumn{2}{|c|}{ Bound critical values } & \multirow[t]{2}{*}{ Decisions } \\
\hline & & & $I(0)$ & $\mathbf{I}(1)$ & \\
\hline$\Delta \operatorname{lnFDI} I_{t}$ & 10.10770 & $1 \%$ & 3.74 & 5.06 & Co-integrated \\
\hline$\Delta \operatorname{lnGDP} \mathrm{t}_{\mathrm{t}}$ & 10.78285 & $1 \%$ & 3.74 & 5.06 & Co-integrated \\
\hline$\Delta \operatorname{lnTON}{ }_{t}$ & 6.075690 & $1 \%$ & 3.74 & 5.06 & Co-integrated \\
\hline$\Delta \operatorname{lnLAF}{ }_{\mathrm{t}}$ & 3.830878 & $10 \%$ & 2.45 & 3.52 & Co-integrated \\
\hline$\Delta \operatorname{lnFER}_{\mathrm{t}}$ & 64.91239 & $1 \%$ & 3.74 & 5.06 & Co-integrated \\
\hline
\end{tabular}

Note: $\left({ }^{* * *}\right),\left({ }^{* *}\right),\left({ }^{*}\right)$ represents $1 \%, 5 \%$ and $10 \%$ level of significant level. Source: Calculation by the author, using E Views 9.

\section{Long-run relationship analyses}

ARDL model $(1,1,1,1,1)$ is used to estimate the long-run coefficients for the variables in the models of the study as resulting in table 3 . The estimated results show the significance of long-run relationships among the variables at $1 \%, 5 \%$, and $10 \%$ level. There are statistically significant long-run relationships between GDP, FER and FDI in Cambodia at significance level of $1 \%$. This implies that an increase of the GDP and FER leads to an increase in the FDI inflows to Cambodia. The report is consistent with the works of Obidike \& Uma (2013). On the contrary, TON has unexpected negative and highly five percent significance level. This finding is against the findings by Azam \& Lukman (2010) for Indonesia; Bekhet \& Al-smadi (2015) for Jordan. However, the result is consistent with Azam \& Lukman (2010) for India. The LAF has a negative significance relationship with FDI, which implies that a higher unemployment rate within unskilled labors supplied in Cambodia discourages the inflows of FDI. This is in line with the reports of Chan (2008) and Hrinc (2010). Moreover, the political instability and deadlock in Cambodia (D01) do not have significant effect on FDI. Furthermore, there is statistically positive and significant relationship between TON, LAF, and GDP, which means that an increasing degree of trade openness and the labor force in Cambodia lead to increase in the GDP.

TABLE 3. Long-run coefficients using ARDL model $(1,1,1,1,1)$

\begin{tabular}{|c|c|c|c|c|c|c|c|}
\hline Models & " Constant & $\operatorname{lnFDI}_{t}$ & $\operatorname{lnGDP}_{t}$ & $\operatorname{lnTON}_{t}$ & $\ln ^{\prime} \mathbf{L A F} F_{t}$ & $\operatorname{lnFER}_{t}$ & D01 \\
\hline$\Delta \ln \mathrm{FDI}_{\mathrm{t}}$ & $209.78^{* * *}$ & & $14.45^{* * *}$ & $-1.78^{* *}$ & $-35.09^{* * *}$ & $1.87^{* * *}$ & -0.23 \\
\hline$\Delta \operatorname{lnGDP} P_{t}$ & $-13.44^{* * *}$ & $0.07^{* * *}$ & & $0.10^{*}$ & $2.61^{* * *}$ & $-0.16^{* * *}$ & 0.01 \\
\hline$\Delta \ln \mathrm{TON}_{\mathrm{t}}$ & $67.41^{* * *}$ & $-0.38^{* * *}$ & $5.30^{* * *}$ & & $-11.86^{* *}$ & $0.60^{*}$ & -0.09 \\
\hline$\Delta \operatorname{lnLAF} F_{t}$ & $1.74^{* * *}$ & 0.02 & -0.59 & 0.46 & & 0.23 & 0.87 \\
\hline$\Delta \operatorname{lnFER}_{\mathrm{t}}$ & $-80.91^{* * *}$ & $0.30^{* * *}$ & $-3.84^{* *}$ & 0.23 & $12.14^{* * *}$ & & 0.01 \\
\hline
\end{tabular}

Note: $\left({ }^{* * *}\right),\left({ }^{* *}\right),\left({ }^{*}\right)$ represents 1\%, 5\% and 10\% level of significance. Source: Calculation by the author, using EViews 9. 


\section{Short-run relationship analyses}

The results of the short-run relationship between dependent and independent variables at $1 \%$ and $\% 5$ significance levels are recorded in table 4.The study reveals that there is a positive relationship between variables $\mathrm{D}(\ln \mathrm{GDP})$, and $\mathrm{D}(\ln \mathrm{FER})$ with the $\Delta \ln F \mathrm{DI}$ model while the variables $\mathrm{D}(\ln \mathrm{TON}), \mathrm{D}(\mathrm{ln} \mathrm{LAF})$ and(D01) are negatively associated with the model. Also, the variables $\mathrm{D}(\operatorname{lnTON})$ and $\mathrm{D}(\mathrm{D} 01)$ have positive relationships with $\triangle$ InGDP model, yet there is a negative relationship between D(ln FER) and the model. It is clear from the results of positive and negative relationships between variables D(Ln FER) and D(D01) with $\Delta$ lnTON model. Also, there is evidence of positive relationships among the variables $\mathrm{D}(\ln \mathrm{GDP})$ and $\mathrm{D}(\operatorname{lnFER})$ with the $\triangle \mathrm{lnLAF}$ model. In addition, the highly significant and negative sign coefficients of 『ECM】_(t-1) for all models indicate a relative speed of achieving the long-run equilibrium.
Specifically, the absolute values of [ECM \_(t-1) coefficients for the $\Delta \operatorname{lnFDI}, \triangle \operatorname{lnGDP}, \Delta \operatorname{lnTON}, \Delta \operatorname{lnLAF}$, and $\triangle \operatorname{lnFER}$ models are $-1.02,-0.81,-1.09,0.07$, and -0.91 , respectively. These confirm that the models are corrected from the short-run towards the long-run equilibrium by $102 \%$, $81 \%, 109 \%, 7 \%$, and $91 \%$, respectively. Therefore, the findings of short-run and ECM_(t-1) strongly present that there is a significant association among FDI inflows, GDP, TON, LAF, FER, and dummy (D01) in Cambodia. The longrun outcome indicates that higher GDP and FER increase FDI inflows, but lower degree of trade openness and low productivity with unskilled labor supplied decrease FDI inflows into Cambodia. Political instability and deadlock is the short-run barrier for the inflows of FDI. These findings are supported by the EMC_(t-1) coefficient of the FDI model, which gives the speed of adjustment from shortrun towards long-run equilibrium.

TABLE 4. Short-run coefficients using ARDL model $(1,1,1,1,1)$

\begin{tabular}{clllllll}
\hline \hline Models & D(InFDI) & D(lnGDP) & D $(\operatorname{lnTON})$ & $\mathbf{D}(\operatorname{lnLAF})$ & $\mathbf{D}(\operatorname{lnFER})$ & $\mathbf{D}(\mathbf{D 0 1})$ & ECM(-1) \\
\hline$\Delta \operatorname{lnFDI}_{\mathrm{t}}$ & & $14.86^{* * *}$ & $-1.68^{* * *}$ & $-2.19^{* * *}$ & $1.54^{* * * *}$ & $-0.23^{* * *}$ & $-1.02^{* * *}$ \\
$\Delta \operatorname{lnGDP}_{\mathrm{t}}$ & $0.05^{* * *}$ & & $0.09^{* * *}$ & 0.40 & $-0.11^{* * *}$ & $0.01^{* *}$ & $-0.81^{* * *}$ \\
$\Delta \operatorname{lnTON}_{\mathrm{t}}$ & -0.37 & $5.60^{* * *}$ & & 1.32 & $0.45^{* * *}$ & $-0.10^{* * *}$ & $-1.09^{* * *}$ \\
$\Delta \operatorname{lnLAF}_{\mathrm{t}}$ & -0.003 & $0.12^{* *}$ & 0.01 & & $0.02^{* * *}$ & 0.004 & $-0.07^{* * *}$ \\
$\Delta \operatorname{lnFER}_{\mathrm{t}}$ & $0.21^{* * *}$ & $-4.58^{* * *}$ & $0.29^{* *}$ & 2.64 & & 0.002 & $-0.91^{* * *}$ \\
\hline \hline
\end{tabular}

Note: $\left({ }^{* *}\right),\left({ }^{* *}\right),\left({ }^{*}\right)$ represents 1\%, 5\% and 10\% level of significance. Source: Calculation by the author, using EViews 9.

\section{Diagnostics Test Results}

Several diagnostic tests are used to ensure no spurious results are produced by the models. The results indicate the accepted hypothesis of no serial correlation, no heteroscedasticity, and normal distribution. Also the stability test confirms the models are stable as shown in figure 1 to figure 5.These tests confirm that all models are reliable.

TABLE 5: Diagnostic tests for selected ARDL model $(1,1,1,1,1)$

\begin{tabular}{llllll}
\hline \hline Test series & LnFDI & LnGDP & LnTON & LnLAF & LnFER \\
\hline Serial Correlation LM test & $0.01(0.90)$ & $0.10(0.65)$ & $0.51(0.29)$ & $0.003(0.93)$ & $0.25(0.45)$ \\
Normality test (Jarque-Bera test) & $1.16(0.56)$ & $0.69(0.70)$ & $0.64(0.73)$ & $1.43(0.50)$ & $0.19(0.91)$ \\
White Heteroskedasticity & $0.51(0.71)$ & $0.96(0.41)$ & $2.62(0.12)$ & $0.71(0.56)$ & $3.04(0.11)$
\end{tabular}

Note: the parentheses are the value of the probability. 


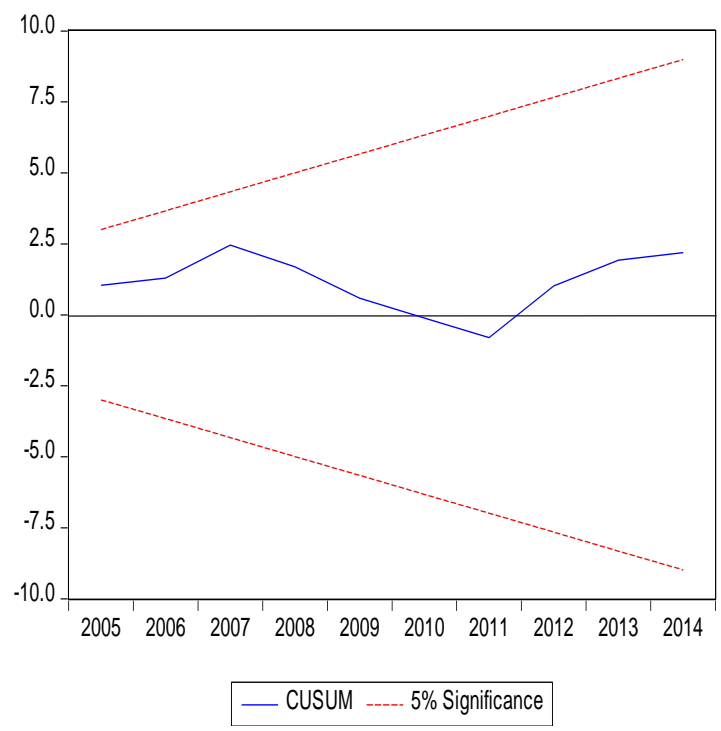

FIGURE 1. Plot of CUSUM for lngdp

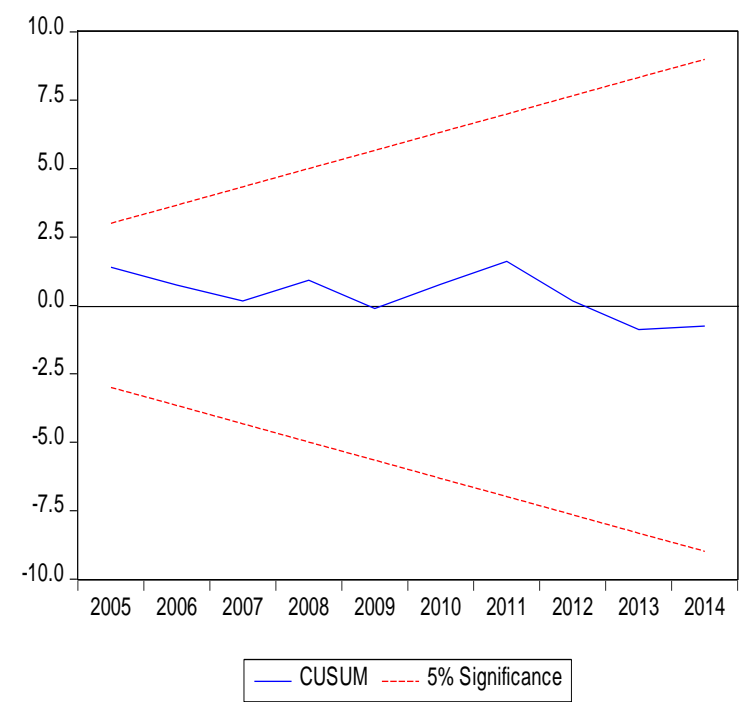

FIGURE 2. Plot of CUSUM for Infdi

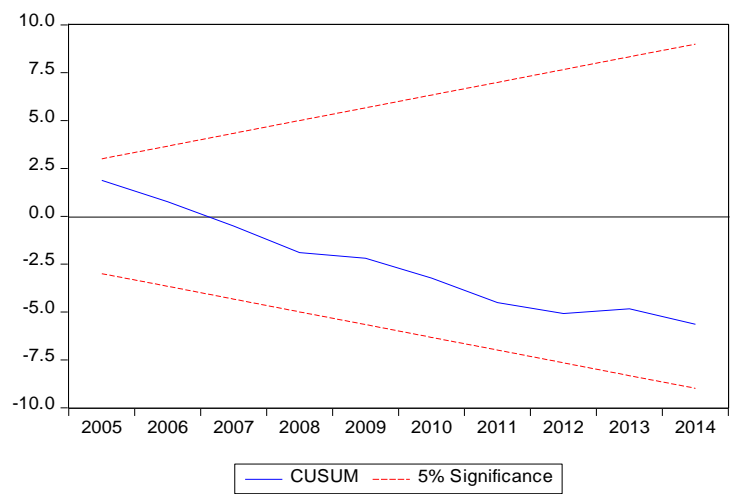

FIGURE 3. Plot of CUSUM for lnton

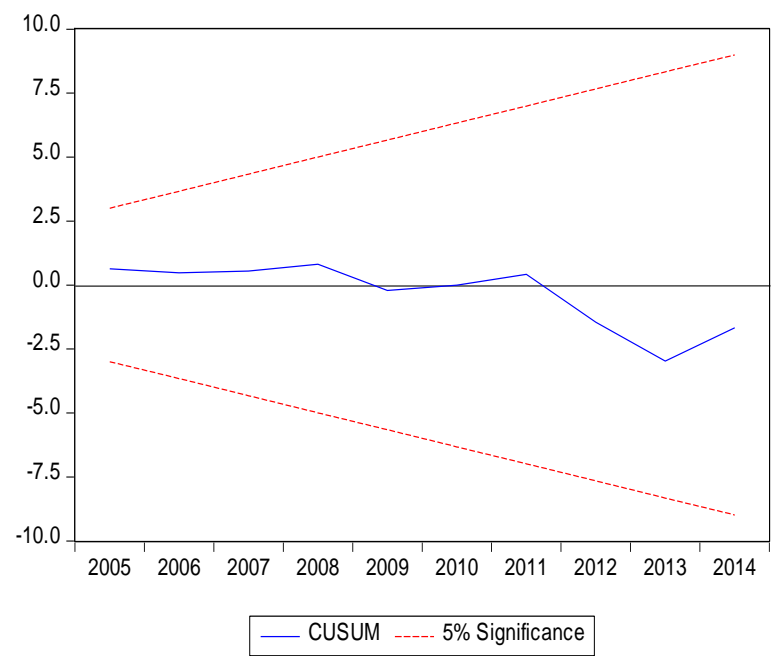

FIGURE 4. Plot of CUSUM for lnlaf

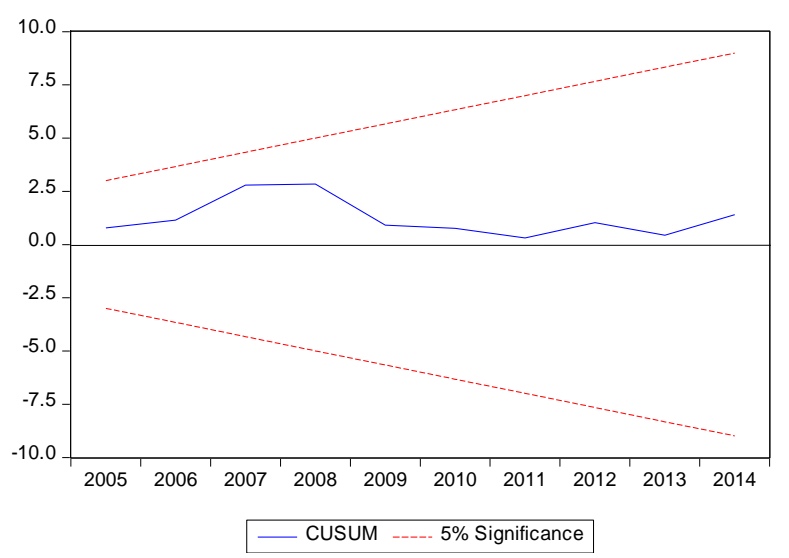

FIGURE 5. Plot of CUSUM for lnfer

\section{Granger Causality Test Results}

After there are evidences of long-run existence among variables as mentioned in section 5.2, the Granger causality test is used to examine the causal relationship of the variables whether its unidirectional, bidirectional or neutral causality. The results computed by E Views 9 show that there is evidence of bi directional relationship between FDI and GDP, GDP and LAF, TON and LAF, and FER and LAF. On the other hand, there is evidence of a unidirectional causal relationship from FDI to D01; GDP to TON and FER, as well as the unidirectional causal relationship exists from TON to FER. Besides, the results also indicate that there is no evidence of causal relationships between FDI and TON, LAF and FER. Also, there is no causal relationships between GDP and D01, TON and D01, LAF and D01, and D01 and FER. 
TABLE 6. Pair wise Granger causality test results

\begin{tabular}{|c|c|c|c|c|}
\hline Variables & F-statistic & P-value & Significance level & Direction of causality \\
\hline $\mathrm{FDI}_{\mathrm{t}} \leftarrow \mathrm{GDP}_{\mathrm{t}}$ & 2.88 & 0.10 & 0.10 & Bidirectional \\
\hline $\mathrm{FDI}_{\mathrm{t}} \rightarrow \mathrm{GDP}_{\mathrm{t}}$ & 3.51 & 0.08 & 0.10 & \\
\hline $\mathrm{FDI}_{\mathrm{t}} \neq \mathrm{TON}_{\mathrm{t}}$ & 1.59 & 0.22 & Insignificant & Neutral causality \\
\hline $\mathrm{FDI}_{\mathrm{t}} \neq \mathrm{TON}_{\mathrm{t}}$ & 0.98 & 0.33 & Insignificant & \\
\hline $\mathrm{FDI}_{\mathrm{t}} \neq \mathrm{LAF}_{\mathrm{t}}$ & 1.97 & 0.17 & Insignificant & Neutral causality \\
\hline $\mathrm{FDI}_{\mathrm{t}} \neq \mathrm{LAF}_{\mathrm{t}}$ & 0.07 & 0.80 & Insignificant & \\
\hline $\mathrm{FDI}_{\mathrm{t}} \neq \mathrm{FER}_{\mathrm{t}}$ & 0.83 & 0.37 & Insignificant & Neutral causality \\
\hline $\mathrm{FDI}_{\mathrm{t}} \neq \mathrm{FER}_{\mathrm{t}}$ & 2.42 & 0.14 & Insignificant & \\
\hline $\mathrm{FDI}_{\mathrm{t}} \leftarrow \mathrm{D} 01_{\mathrm{t}}$ & 0.62 & 0.44 & Insignificant & Unidirectional \\
\hline $\mathrm{FDI}_{\mathrm{t}} \rightarrow \mathrm{D} 01_{\mathrm{t}}$ & 2.92 & 0.10 & 0.10 & \\
\hline $\mathrm{GDP}_{\mathrm{t}} \leftarrow \mathrm{TON}_{\mathrm{t}}$ & 0.05 & 0.83 & Insignificant & Unidirectional \\
\hline $\mathrm{GDP}_{\mathrm{t}} \rightarrow \mathrm{TON}_{\mathrm{t}}$ & 7.73 & 0.01 & 0.5 & \\
\hline $\mathrm{GDP}_{\mathrm{t}} \leftarrow \mathrm{LAF}_{\mathrm{t}}$ & 6.52 & 0.01 & 0.5 & Bidirectional \\
\hline $\mathrm{GDP}_{\mathrm{t}} \rightarrow \mathrm{LAF}_{\mathrm{t}}$ & 4.33 & 0.05 & 0.5 & \\
\hline $\mathrm{GDP}_{\mathrm{t}} \leftarrow \mathrm{FER}_{\mathrm{t}}$ & 0.004 & 0.96 & Insignificant & Unidirectional \\
\hline $\mathrm{GDP}_{\mathrm{t}} \rightarrow \mathrm{FER}_{\mathrm{t}}$ & 104.76 & 6.E-09 & 0.01 & \\
\hline $\mathrm{GDP}_{\mathrm{t}} \neq \mathrm{D} 01_{\mathrm{t}}$ & 0.54 & 0.47 & Insignificant & Neutral causality \\
\hline $\mathrm{GDP}_{\mathrm{t}} \neq \mathrm{D} 01_{\mathrm{t}}$ & 0.34 & 0.56 & Insignificant & \\
\hline $\mathrm{TON}_{\mathrm{t}} \leftarrow \mathrm{LAF}_{\mathrm{t}}$ & 10.03 & 0.005 & 0.01 & Bidirectional \\
\hline $\mathrm{TON}_{\mathrm{t}} \rightarrow \mathrm{LAF}_{\mathrm{t}}$ & 4.43 & 0.05 & 0.5 & \\
\hline $\mathrm{TON}_{\mathrm{t}} \leftarrow \mathrm{FER}_{\mathrm{t}}$ & 3.76 & 0.06 & 0.10 & Unidirectional \\
\hline $\mathrm{TON}_{\mathrm{t}} \rightarrow \mathrm{FER}_{\mathrm{t}}$ & 0.77 & 0.39 & Insignificant & \\
\hline $\mathrm{TON}_{\mathrm{t}} \neq \mathrm{D} 01_{\mathrm{t}}$ & 0.58 & 0.45 & Insignificant & Neutral causality \\
\hline $\mathrm{TON}_{\mathrm{t}} \neq \mathrm{D} 01_{\mathrm{t}}$ & $4.3 \mathrm{E}-05$ & 0.99 & Insignificant & \\
\hline $\mathrm{FER}_{\mathrm{t}} \rightarrow \mathrm{LAF}_{\mathrm{t}}$ & 6.62 & 0.02 & 0.05 & Bidirectional \\
\hline $\mathrm{FER}_{\mathrm{t}} \leftarrow \mathrm{LAF}_{\mathrm{t}}$ & 93.40 & 2.E-08 & 0.01 & \\
\hline $\mathrm{LAF}_{\mathrm{t}} \neq \mathrm{D} 01_{\mathrm{t}}$ & 0.42 & 0.52 & Insignificant & Neutral causality \\
\hline $\mathrm{LAF}_{\mathrm{t}} \neq \mathrm{D} 01_{\mathrm{t}}$ & 0.23 & 0.63 & Insignificant & \\
\hline $\mathrm{D} 01_{\mathrm{t}} \neq \mathrm{FER}_{\mathrm{t}}$ & 0.002 & 0.96 & Insignificant & Neutral causality \\
\hline $\mathrm{D} 01_{\mathrm{t}} \neq \mathrm{FER}_{\mathrm{t}}$ & 0.48 & 0.49 & Insignificant & \\
\hline
\end{tabular}

Note: The signs " $\rightarrow$ ", “ $\neq$ " denote the unidirectional causality and the neutral causality, respectively. 


\section{CONCLUSION}

The paper investigates the long and short-run relationships among the variables over the period of 22 years (1993-2014) by employing ARDL bounds testing model and vector error correction model (VECM). Also, Granger causality test is used to explore the direction of causality among the variables. We found that there is the presence of long-run relationships among FDI and its determinants (GDP, TON, LAF, and FER) for all the models. Specifically, GDP and FER have statistical and significant positive relationships with FDI for both long and short run. This implies that an increasing GDP and foreign exchange reserve lead to an increase in the FDI inflows in Cambodia. On the other hand, TON has significant and negative long and short-run relationships with FDI, which is an unexpected result. Expected sign of LAF has the negative effect on FDI inflows into Cambodia. This indicates that higher unskilled labors supplied in Cambodia discourage FDI inflows to the country. The political instability and deadlock in Cambodia have the negative short-run impact of FDI inflows. Moreover, the higher degree of trade openness and the labor force in Cambodia lead to increase in the GDP. In addition, the highly significant and negative sign coefficients of [ECM)_(t-1) for all models indicate a relative speed of achieving the long-run equilibrium. The absolute values of [ECM)_(t-1) coefficients for the $\Delta \operatorname{lnFDI}$,
$\Delta \operatorname{lnGDP}, \Delta \operatorname{lnTON}, \Delta \ln L A F$, and $\Delta \operatorname{lnFER}$ models are -1.02, $0.81,-1.09,0.07$, and -0.91 , respectively. These confirm that the models are corrected from the short-run towards the long-run equilibrium by $102 \%, 81 \%, 109 \%, 7 \%$, and $91 \%$, respectively. The Granger causality test shows that there is evidence of bidirectional relationship between FDI and GDP, GDP and LAF, TON and LAF, and FER and LAF. On the other hand, there is evidence of a unidirectional causal relationship from FDI to D01; GDP to TON and FER, as well as from TON to FER. And, there is no evidence of causal relationships between FDI and TON, LAF and FER, GDP and D01, TON and D01, LAF and D01, and D01 and FER. Results from this study suggest that the government should protect the internal political conflict as well as increase degree of trade openness and skilled labors. This study provides vital information for the Cambodian government and policy makers to establish the right policy in order to attract more potential foreign direct investment into Cambodia. More than that, the study contributes to literature review in the case of Cambodia.

\section{ACKNOWLEDGMENTS}

I would like to deeply thank to Vongchavalitkul University for the financial support. I also would like to thank for anonymous authors for methodology's suggestion.

\section{REFERENCES}

Adam, A.M., \& Tweneboah, G. 2009. Foreign direct investment and stock market development: Ghana's evidence. International Research Journal of Finance \& Economics, 26: 178-185.

Alhassan, A.L., \& Fiador, V. 2014. Insurance-growth nexus in Ghana: An autoregressive distributed lag bounds cointegration approach. Review of Development Finance, 4(2): 83-96. D0I: 10.1016/j.rdf.2014.05.003

Almsafir, M.K., Latif, N.A., \& Bekhet, H.A. 2011. Analyzing the green field investment in Malaysia from 1970-2009: A bound testing approach. Australian Journal of Basic \& Applied Sciences, 5(3): 561-570.

Amusa, H., Amusa, K., \& Mabugu, R. 2009. Aggregate demand for electricity in South Africa: An analysis using the bounds testing approach to cointegration. Energy Policy, 37(10): 4167-4175. DOI: 10.1016/j.enpol.2009.05.016

Anfofum, A.A., Gambo, J.S., \& Suleiman, T. 2013. Estimating the impact of foreign direct investment in Nigeria. International Journal of Humanities \& Social Science, 3(17): 138-145.

Asien, E.N., \& Oriavwote, V. 2013. Association between foreign capital inflow and macroeconomic factors: Evidence from Nigeria. Journal of Economics \& International Finance, 5(8): 307-317.

Azam, M., \& Lukman, L. 2010. Determinants of foreign direct investment in India, Indonesia and Pakistan: A quantitative approach. Journal of Managerial Sciences, 4(1): 31-44.

Bekhet, H.A., \& Al-Smadi, R.W. 2015. Determinants of Jordanian foreign direct investment inflows: Bounds testing approach. Economic Modeling, 46: 27-35. DOI: 10.1016/j.econmod.2014.12.027

Belloumi, M. 2014. The relationship between trade FDI and economic growth in Tunisia: An application of the autoregressive distributed lag model. Economic Systems, 38(2): 269-287. D0I: 10.1016/j.ecosys.2013.09.002

Cuyvers, L., Plasmans, J., Soeng, R., \& Van den Bulcke, D. 2008. Determinants of foreign direct investment in Cambodia: Country-specific fsctor differentials. Working paper no. 1-34, Centre for ASEAN Studies University of Antwerp, Belgium, BE. 
Cuyvers, L., Soeng, R., Plasmans, J., \& Van Den Bulcke, D. 2011. Determinants of foreign direct investment in Cambodia. Journal of Asian Economics, 22(3): 222-234. DOI: 10.1016/j.asieco.2011.02.002

Chan, S. 2008. Making the most of Cambodia's human resources. Cambodia. Development Review, 12(2): 9-11.

Decastro, P.G., Fernandes, E.A., \& Campos, A.C. 2013. The determinants of foreign direct investment in Brazil and Mexico: An empirical analysis. Procedia Economics \& Finance, 5: 231-240. D0I: 10.1016/S2212-5671(13)00029-4

Demirhan, E., \& Masca, M. 2008. Determinants of foreign direct investment flows to developing countries: A crosssectional analysis. Prague Economic Papers, 24(4): 356-369. DOI: 10.18267/j.pep.337

Egbo, 0., \& Onwumere. 2011. Analysis the impact of foreign direct investment on Nigeria's economy growth: A co integration approach. International Journal of Research in Management, 3(1): 78-97.

Godfrey, L.G. 1978. Testing for higher order serial correlation in regression equations when the regressors include lagged dependent variables. Econometrica: Journal of the Econometric Society, 46(6): 1303-1310. D0I: $10.2307 / 1913830$

Granger, C.W. 1969. Investigating causal relations by econometric models and cross-spectral methods. Econometrica: Journal of the Econometric Society, 37(3): 424-438. D0I: 10.2307/1912791

Hrinc. 2010. Higher eduction and skills for the labor market in Cambodia. URL: http://goo.gl/bvH9WV. Last accessed on 22 July 2015.

Hunady, J., \& Orviska, M. 2014. Determinants of foreign direct investment in EU countries-do corporate taxes really matter? Procedia Economics \& Finance, 12: 243-250. DOI: 10.1016/S2212-5671(14)00341-4

Ho, O.C. 2004. Determinants of foreign direct investment in China: A sectoral analysis. Department of Economics, University of Western Australia. Perth, AU.

Imoudu, E.C. 2012. The impact of foreign direct investment on Nigeria's economic growth; 1980-2009: Evidence from the Johansen's cointegration approach. International Journal of Business \& Social Science, 3(6): $122-134$.

Jarque, C.M., \& Bera, A.K. 1980. Efficient tests for normality, homoscedasticity and serial independence of regression residuals. Economics letters, 6(3): 255-259. DOI: 10.1016/0165-1765(80)90024-5

Keorite, M., Bukhari, G.A.S, \& Chantarat, P. 2015. An analysis of the impact of foreign direct investment by chinese campanies in Thailand. International Journal of Business \& Management Study, 2(2): 307-314.

Kersan-Skabic, I., \& Tijanic, L. 2014. Reginal determinants of foreign direct investments in croatia. [special issue]. Transylvanian Review of Administrative Sciences, 10(SI): 70-89.

Khan, G., \& Mitra, P. 2014. A causal linkage between fdi inflows with select macroeconomic variables in India-an econometric analysis. Journal of Economics \& Finance, 5(5): 124-133.

Kiran, B. 2011. Causal links between foreign direct investment and trade in Turkey. International Journal of Economics \& Finance, 3(2): 150-158. DOI: 10.5539/ijef.v3n2p150

Kunle, A.M., Olowe, S.O., \& Oluwafolakemi, F.O. 2014. Impact of Foreign Direct Investment on Nigeria Economic Growth. International Journal of Academic Research in Business \& Social Sciences, 4(8): 234-242.

Leopold, G., \& Maniam, B. 2006. Foreign direct investment in the united states: Country analysis. Journal of Economics \& Economic Education Research, 7(1):81-97.

Mottaleb, K.A., \& Kalirajan, K. 2010. Determinants of foreign direct investment in developing countries a comparative analysis. The Journal of Applied Economic Research, 4(4): 369-404. DOI: 10.1177/097380101000400401

Onuorah, A.C.C., \& Nnenna, O.M. 2013. Long run relationship between macroeconomic variables and FDI in Nigeria. Developing Country Studies, 3(1): 162-169.

Obidike, P., \& Uma, K. 2013. Effects of macroeconomic variables on foreign direct investment in a liberalized economy: The case of Nigeria. Journal of Economics and Finance, 1(4): 12-20.

Onyeiwu, S. 2003. Analysis of FDI flows to developing countries: Is the MENA region different. Paper presented at the 10th annual conference in ERF, Marrakech, MA.

Pesaran, M., Shin, Y., \& Smith, R. 1999. Bounds testing approaches to the analysis of long run relationship. Working paper no 9907, Department of Applied Economics, Unveristy of Cambridge, UK.

Pesaran, M.H., Shin, Y., \& Smith, R.J. 2001. Bounds testing approaches to the analysis of level relationships. Journal of Applied Econometrics, 16(3): 289-326. DOI: 10.1002/jae.616

Plc, P.P. 2011. Foreign direct investment in Cambodia. URL: http://goo.gl/4T1kjs. Last accessed on 22 July 2016.

Rodriguez, X.A., \& Pallas, J. 2008. Determinants of foreign direct investment in Spain. Applied Economics, 40(19): 24432450. DOI: $10.1080 / 00036840701367606$

Teli, R.B. 2014. A critical analysis of foreign direct investment inflows in India. Procedia-Social \& Behavioral Sciences, 133: 447-455. D0I: 10.1016/j.sbspro.2014.04.211

Tsen, W.H. 2005. The determinants of foreign direct investment in the manufacturing industry of Malaysia. Journal of Economic Cooperation, 26(2): 91-110. 
Uwubanmwen, A.E., \& Ajao, M.G. 2012. The determinants and impacts of foreign direct investment in Nigeria. International Journal of Business \& Management, 7(24): 67-77.

White, H. 1980. A heteroskedasticity-consistent covariance matrix estimator and a direct test for heteroskedasticity. Econometrica: Journal of the Econometric Society,48(4): 817-838. D0I: 10.2307/1912934

— This article does not have any appendix. - 